Technological University Dublin ARROW@TU Dublin

\title{
Labour Turnover in London Hotels and the Cost Effectiveness of Preventative Measures
}

\author{
Frank McMahon \\ Technological University Dublin, frank.mcmahon@tudublin.ie \\ Ann Denvir \\ Technological University Dublin
}

Follow this and additional works at: https://arrow.tudublin.ie/diraaart

Part of the Hospitality Administration and Management Commons

\section{Recommended Citation \\ MzMahon, F. \& Denvir, A. (1992) Labour Turnover in London Hotels and the Cost Effectiveness of Preventative Measures, International Journal of Hospitality Management, Vol. 11, no. 2, pp.143-154. DOI: 10.1016/0278-4319(92)90007-I}

This Article is brought to you for free and open access by the Directorate of Academic Affairs at ARROW@TU Dublin. It has been accepted for inclusion in Articles by an authorized administrator of ARROW@TU Dublin. For more information, please contact arrow.admin@tudublin.ie, aisling.coyne@tudublin.ie, gerard.connolly@tudublin.ie.

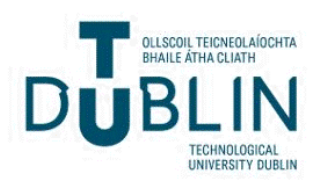




\title{
Labour turnover in London hotels and the cost effectiveness of preventative measures
}

\author{
Ann Denvir and Frank McMahon \\ Dublin College of Catering, Cathal Brugha Street, Dublin 1, Ireland
}

\begin{abstract}
This study reviews the effect of labour turnover on organizations generally and methods used to reduce the impact of such turnover. A study of the level of turnover in four large London hotels is reported showing annual turnover rates between $58 \%$ and $112 \%$. The varying practices of the hotels in regard to recruitment, selection, induction, and training are documented. The cost of preventative measures is given and the tentative conclusion drawn that some hotels may be spending more on prevention of labour turnover than is justified.
\end{abstract}

Key words: labour turnover London hotels personnel costs

\section{Introduction}

Labour turnover is the movement of people into and out of employment within an organization. The pervasive impacts of labour turnover are rarely realised, both in magnitude of costs and also in terms of employee and customer satisfaction. Labour turnover is of particular importance in the hotel industry due to the high levels of customer-staff contact. A satisfied, motivated and stable workforce is therefore a critical success factor. The termination of an employees contract with his/her employer is in fact only the final stage of a sequence of events and provides the ultimate expression of discontent.

Human Resource Management policies and practices in the lodging industry are not conducive to long term employment . . . managers have tended to espouse a philosophy of low salaries and wages coupled with long hours and a general disregard for the individual worker (Hiemstra, 1990).

High labour turnover is very costly; the level of tangible costs involved will depend greatly upon company policies of expenditure. The intangible costs are innumerable and serious and both will affect the success and profitability of the firm. It is important that retention practices are not even more costly.

\section{Labour turnover}

(a) Labour turnover is viewed as a relatively recent phenomenon and has been linked to the advent of 'replacement' (Samuel, 1969). Labour turnover is not an isolated occur- 
rence, but a multidimensional 'problem': There is a tendency in industry to impose cut-off points in time and content of problems of labour turnover, low employee morale, absenteeism, bad timekeeping and substandard work performance. In a very real sense, all these problems can be grouped meaningfully under a general heading which might be referred to as "underutilisation of human resources" (Samuel, 1969).

Labour turnover can be categorised as voluntary or involuntary according to whom the obligation to leave derives from. Much research has focused on the reasons why voluntary labour turnover occurs. Wild and Dawson (1972) discuss the view that some "workers quit their jobs for no rational, predictable or identifiable reason, and consequently that it is beyond the capability of management to reduce such turnover'. However, many theorists have indicated characteristics inherent in the person, in the job and in the environment which will lead to an increase in worker mobility (Samuel, 1969; Pettman, 1974; Bevan, 1987; Wild and Dawson, 1972).

In other words, it is possible to indicate, at least on a general basis, the causes and conditions that impinge upon this final decision to leave.

(b) Other forms of withdrawal from work such as absenteeism and sickness, although not as final as the act of leaving, can have a substantial impact upon the organization. Attention to the expression of such dissatisfaction, which constitutes the longer withdrawal process, may act as a prevention for turnover. 'Adequate prevention should obviate the need for remedy', however, in practice, preventative measures may be costlier than remedies and neither course of action is likely to be successful (Samuel, 1969).

Publication of research by the Tavistock Institute of Human Relations in the 1950s suggested that labour turnover should be viewed as a "social process", and that attention should be directed towards the 'following-up' of entrants rather than a mere analysis of leavers. This report conceptualised the turnover process in terms of the now familiar'induction crisis', 'differential transit' and 'settled connection'. Many studies have proposed that a high labour turnover situation will usually deteriorate even further. The Tavistock Institute referred to this phenomenon as the 'self-aggravating, self-generating nature of labour turnover'.

(c) High levels of labour turnover can have a substantial and detrimental impact upon the organization; 'Discontinuity of employment discourages some people from entering the industry and encourages others to leave it as they grow older. It prevents continuing relationships between employers and employees and so inhibits the growth of mutual responsibility. It involves heavy administration costs and a substantial loss of productivity through the breaking up of teams who are used to working together' (Samuel, 1969).

Excessive labour turnover can be a reliable indicator of many factors; 'Labour turnover as characterised by voluntary resignation from employment, can be both costly and disruptive. It can indicate the presence of seriously disadvantageous external labour market comparisons in terms of pay and benefits. It can also provide a pointer to morale and satisfaction problems within an organisation. Turnover also represents an oufflow of skills and experience from the firm which, in terms of replacement and retraining costs, can seriously hinder competitiveness and efficiency' (Bevan, 1987).

(d) Extensive theories regarding labour turnover have been developed. Pcttman (1974) highlights four main theories which have been isolated by researchers in relation to labour turnover. According to these propositions successively higher amounts of pay, partici- 
pation, communication and decentralization within the organization will be likely to produce successively lower amounts of turnover.

These theories are further qualified by the inclusion of two important intervening variables which occur at different times. The first variable, a social-psychological variable conceptualised in 'cost-benefit terms' precedes the second, the structural variable of 'opportunity'.

It is noted that dissatisfaction with internal factors is of more relevance than attraction of external factors, and it is suggested that the decision to leave is based upon the perceived desirability of leaving and the perceived ease of movement (Bevan, 1987).

\section{Retention}

(a) Due to the impact that high labour turnover can have on the stability, profitability. productivity and overall success of the firm, retention becomes a key issue. This is the reduction of staff mobility through a range of financial and motivational incentives such that staff increase their length of service with any one company. Two fundamental theoretical approaches provide an important contribution to understanding the complex interaction of the individual and the workplace: 'job satisfaction' and 'occupational role integration'.

(b) Job satisfaction can be clearly linked with labour turnover, absentecism and low morale. 'A variety of previous research studies have indicated that levels of job satisfaction are strongly related to the decision to terminate employment' (Bevan, 1987). Interest in job satisfaction has been maintained due to the high cost factor involved, as there are financial implications whether the dissatisfied employee stays or leaves. Kiely (1986) emphasises that "no study has shown the dynamics of how the job environment, economic environment and home environment interact to influence job satisfaction over time'. The many dimensions of job satisfaction include the commitment the individual feels, the rewards received and the management style or 'framework' through which the worker is controlled.

(c) The argument regarding 'occupational role' and its impact upon retention is as follows: The process of occupational role integration occurs when the incumbent begins to perceive no mismatch between job-requirements, job-expectations, job-performance and job-experience. As occupational role integration increases, the incumbent becomes less willing to change or modify his/her role and consequently less likely to leave it. The process of occupational role integration can also lead to a more general phenomenon, that is 'institutionalisation', whereupon people will not change or leave their job, although not necessarily satisfied. 'The analysis indicates that low labour turnover may be the result of high levels of occupational role integration, not high levels of job satisfaction . . . it may be based on a false consciousness created by ageing, routinization, lack of autonomy and information, tight controls, uncertainty and [lack of] real or perceived opportunities in the labour market' (Gowler and Legge, 1975).

This phenomenon of 'institutionalisation', which has also been researched by Palmer $e t$ al. (1972), was cited owing to the fact that often there may be high levels of labour turnover accompanied by equally high levels of labour stability. Therefore stability will arise in a 
company, though not necessarily satisfaction, and the worker will be very much tied to the company as a result of accrued bencfits.

(d) The work values which an individual holds will also affect levels of satisfaction and stability within the organization (Blennerhassett, 1983). Motivation of staff requires an understanding of the individuals value system, work expectations and experience, and many other dynamics which shape the individual personality. Efrective motivation has been positively linked with job satisfaction and accordingly retention of staff (Atkinson, 1981).

\section{The hotel industry}

(a) In the hotel industry, high turnover can result in compromised service standards, poor productivity and low morale. High turnover will lead to the reduction of both real and perceived managerial effectiveness while also interfering with the personal development of employees, quality of training and group cohesiveness as a whole. As the interaction between customer and the employee determines the quality of service, the overall success of the firm is ultimately affected.

A company-wide commitment is required in order to develop retention programmes and the culture that supports them. Effectiveness is a crucial consideration as costly exercises which occupy only a marginal role in detcrmining propensity to stay or leave may further aggravate the cost implications of high turnover.

(b) The modern hotel industry has evolved considerably since its inception and has experienced significant changes over the past twenty years (Jones and Lockwood, 1989).

The structure of employment has undergone extensive change in recent years. In the U.K., for instance, this sector, according to the Institute of Manpower Studies (1989), has been 'far outstripping growth in the economy as a whole. Over the past five years ... employment has increased by $23 \%$ compared with $5 \%$ in all other industries'.

This creates certain challenges, but also many problems. It has been noted that 'most jobs were characterised by young recruits, little training, less promotion and high turnover" (I.M.S., 1989). This has led to high levels of labour turnover: "On average, hospitality operations replace their entire workforce every four months. For most industries, the average employee stays on the job 4.2 years' (Woods and Macauley, 1989).

Although the above-mentioned challenges will face most industries, it is believed that the hotel industry will be particularly affected; 'Within this competition the industry as a whole is likely to do relatively badly because of its poorer image, lower career potential, lower pay and benefits and less sophisticated personnel practices" (I.M.S., 1989).

(c) Research has indicated that hotels differ markedly from each other in their experience of labour turnover (E.D.C., 1969). This finding confirms the view that turnover is partly within the control of management, and conflicts with the widespread impression that turnover is high and uniform throughout the industry. In fact, labour turnover is often viewed as a positive function of redistribution: 'Job changes, a necessary function of labour mobility, is a useful process through which the workforce may expand or contract. For the individual worker it is the means by which he may gain in work experience, rapidly leading perhaps to increased status and rewards in an industry of small units' (Knight, 1971). 
(d) Hotels have two significant constraints which must be taken into consideration when dealing effectively with retention problems, namely business demands and traditions (I.M.S., 1989).

Instead of tackling these constraints many hotels have adopted short-term prescriptive measures. Articles with exhaustive lists of 'effective' retention policies and schemes are plentiful (Hospitality, 1985), (Canadian Hotel and Restaurant, 1990). The incentives and benefits range from the cost-free to the novel and extravagant. The basic similarity between all of these enticements is the claim that they are successful retention devices. Evidence is however scarce and inconclusive. Retention programmes in the hotel industry, while becoming more innovative, may only deal partly with the problem of dissatisfied employees.

(e) Due to the problems of recession, intense competion and labour market difficulties, the importance of retaining staff is increasing. It is therefore necessary to explore realistically flexible alternatives that will enable the retention of service-oriented individuals (Magnan, 1990/91).

Strategies designed to remedy excess turnover must be multifaceted and address the specific needs of the work environment (McFillan et al., 1986). It is therefore necessary to create an environment which fosters the retention of high quality employees, while holding no particular attraction for marginal performers.

\section{Human resource investment}

(a) Human resource investment is typically associated with 'profit absorption' and the human resource department considered a 'cost centre'. If investment can be illustrated as justifiable through measurement, the contribution of human resources to the success of the organization becomes less elusive. This should in turn facilitate even more effective investment decisions.

(b) Many factors in an organization impact upon the level of labour turnover and the quality of retention, whether intentional or not. Due to its multi-dimensional nature, many firms fail to evaluate the implications of high turnover or the cost-effectiveness of retention procedures. Turnover may be very high and consequently very costly, but it is important that retention procedures, designed to counteract the harmful effects, are not wasteful. Justification should be in terms of costs, specifically as related to the costs of turnover, and generally as related to the benefits that will be accrued as a result of these practices.

\section{An evaluation of the costs of labour turnover and the cost-effectiveness of preventive measures}

\subsection{Primary research}

Primary research was undertaken to establish the costs of labour turnover and accordingly to consider whether the costs of retention practices were justifiable. The procedure involved in achieving this objective was the formulation of a detailed questionnaire to obtain relevant information of a quantitative and qualitative nature with relation to the 
following areas: recruitment, selection and placement, induction, separation, prevention, appraisals, absenteeism and general personnel and training costs.

\subsection{Hotels}

Four hotels of an equal calibre were chosen for the analysis. All hotels are grade $4 \star$, and are located, at close proximity to each other, in the west-end of London. All hotels attract a similar clientele and aim to provide a relatively similar 'product' and standard of service. The four hotels compete within the same labour market and experience the same external influences.

The sample chosen is fairly typical of the London hotel industry and will be found to be generally consistent with similar calibre hotels in London. Research is based on the year 1990. The costs provided by the hotels were of a detailed and confidential nature and all costs were found to be fairly representative of previous years and general trends.

\subsection{Labour turnover}

All hotels employ a proportion of seasonal workers, students and foreign workers giving rise to relatively higher rates of turnover in the summer months. Variation in turnover rates is evident among all hotels. Hotels A and B have similar 'lengths of stay', whereas Hotel $\mathrm{C}$ is the most 'stable' of the four. Reasons cited for leaving are primarily those of 'going abroad', 'better compensation and benefits' and a 'career progression'. Those were similar for all the hotels in the analysis.

\begin{tabular}{|c|c|c|c|c|}
\hline \multicolumn{5}{|l|}{$\begin{array}{l}\text { Hotel } \\
\text { information }\end{array}$} \\
\hline Hotel grade & $4^{*}$ & $4^{*}$ & $4^{*}$ & $4^{*}$ \\
\hline $\begin{array}{l}1990 \text { occupancy \% } \\
\text { Number of lounges/ }\end{array}$ & $80.96 \%$ & $80.3 \%$ & $79 \%$ & $85 \%$ \\
\hline & 1 & 3 & 3 & 2 \\
\hline & 400 & 800 & 800 & 400 \\
\hline per night & $\mathfrak{f} 105$ & f89 & f90 & f88 \\
\hline \multicolumn{5}{|l|}{ Staff information } \\
\hline $\begin{array}{l}1990 \text { average staff } \\
1990 \text { wage cost }\end{array}$ & 180 & 381 & 472 & 190 \\
\hline ( $\%$ revenue) & $20 \%$ & - & $27 \%$ & $33.7 \%$ \\
\hline \multicolumn{5}{|l|}{ Labour turnover } \\
\hline $\begin{array}{l}1990 \% \\
\text { Average stay }\end{array}$ & 111.58 & 72.60 & 81.54 & 58.13 \\
\hline Operative & 6 months & 6 months & 8-12 months & 12 months \\
\hline Management & 1 year & 1.5 years & $3-5$ years & 3 years \\
\hline
\end{tabular}




\subsection{Recruitment, selection and placement}

There is considerable variation with regard to recruitment. When recruiting Hotel $\mathrm{C}$ spends $£ 218$ per starter, Hotel D spends $£ 206$ per starter and, by contrast, Hotel A spends $£ 50$ per starter. The high costs of Hotels $C$ and D should imply the recruitment of higher quality and more suitable staff and should favourably affect the 'stability' of the hotel.

All hotels operate a similar selection and placement procedure, as can be seen from the table below.

Table 2. Recruitment, selection and placement policies

\begin{tabular}{|c|c|c|c|c|}
\hline Recruitment & Hotel A & Hotel B & Hotel C & Hotel D \\
\hline Recruitment methods & $\begin{array}{l}\text { Advertising } \\
\text { agencies } \\
\text { Referrals } \\
\text { Passers-by } \\
\text { Letters of } \\
\text { request } \\
\text { Job centre }\end{array}$ & $\begin{array}{l}\text { Advertising } \\
\text { agencies } \\
\text { Referrals } \\
\text { Passers-by } \\
\text { Letters of } \\
\text { request } \\
\text { Job centre }\end{array}$ & $\begin{array}{l}\text { Advertising } \\
\quad \text { agencies } \\
\text { Referrals } \\
\text { Passers-by } \\
\text { Letters of } \\
\quad \text { request } \\
\text { Job centre } \\
\text { Open days } \\
\text { Career fairs } \\
\text { College visits } \\
84.030\end{array}$ & $\begin{array}{l}\text { Advertising } \\
\quad \text { agencies } \\
\text { Referrals } \\
\text { Passers-by } \\
\text { Letters of } \\
\text { request }\end{array}$ \\
\hline \multicolumn{5}{|l|}{$\begin{array}{l}\text { Selection and } \\
\text { placement }\end{array}$} \\
\hline Interviewer & $\begin{array}{c}\text { Personnel and } \\
\text { department } \\
\text { manager }\end{array}$ & $\begin{array}{l}\text { Personnel and } \\
\text { Department } \\
\text { manager }\end{array}$ & $\begin{array}{l}\text { Recruitment } \\
\text { officer and } \\
\text { Department } \\
\text { manager }\end{array}$ & $\begin{array}{l}\text { Head of } \\
\text { Department }\end{array}$ \\
\hline Duration of interviews & $20 \mathrm{~min}$ & $\begin{array}{l}\text { Operative } \\
20 \text { min } \\
\text { Management } \\
40-90 \mathrm{~min}\end{array}$ & $\begin{array}{l}\text { At least } \\
30 \text { min }\end{array}$ & $30 \mathrm{~min}$ \\
\hline No. per year & $600-800$ & 670 & 1200 & 500 \\
\hline
\end{tabular}

\subsection{Induction}

There is a great difference between the hotels at induction stage. The lengthy induction of Hotels $B$ and $C$ should ideally result in higher quality service, better adaptability of staff to company culture and reduce the risk of 'induction crisis'. The induction programme at Hotel $\mathrm{B}$ is both innovative and novel, however its relevance could be questioned in the light of the higher costs and departmental disruptions involved.

Induction costs are far greater in Hotel $\mathrm{C}$ relative to the others hotels, and as a result high turnover will have an even greater financial impact. This expenditure could however be viewed as potentially constructive. 
Table 3. Induction methods of four hotels compared

\begin{tabular}{|c|c|c|c|c|}
\hline Induction & Hotel A & Hotel B & Hotel C & Hotel D \\
\hline \multicolumn{5}{|l|}{ Programme length } \\
\hline Hours & 4 & 50 & 24 & 4 \\
\hline Days & 1 & 6 and $1 / 4$ & $\begin{array}{l}5 \text { full } \\
4 \text { half }\end{array}$ & 1 \\
\hline $\begin{array}{l}\text { Duration of } \\
\text { departmental induction }\end{array}$ & $15 \mathrm{hr}$ & $4 \mathrm{hr}$ & $64 \mathrm{hr}$ & $40 \mathrm{hr}$ \\
\hline Total cost & 13,000 & 21,789 & 81,190 & 10,530 \\
\hline
\end{tabular}

\subsection{Separation}

At the separation stage, a great deal of time and effort is required on the part of personnel department. In Hotel C, 15 weeks are required per year solely to deal with arrangements for leavers.

The analysis highlights two problems for Hotel A. Primarily the use of 'exit interviews' is infrequent and it is therefore difficult to formulate effective remedial action if both the attitudes of leavers and their reasons for leaving are not known. Secondly, research indicates that due to high overtime and agency costs at this stage, the recruitment procedure is not as timely as necessary.

Table 4. Policies on staff separations

\begin{tabular}{lllll}
\hline Separation & Hotel A & Hotel B & Hotel C & Hotel D \\
\hline Exit interview & 1 in 10 & 1 in 3 & All staff & All staff \\
Duration & $1 \mathrm{hr}$ & $15-20$ mins & 30 mins & 15 mins \\
Overtime/agency (per leaver) & $2 / 3$ days & Not measured & Not required & Not required \\
\hline
\end{tabular}

\subsection{Prevention and general personnel and training costs}

Preventive procedures are those that attempt to increase staff skills, promotion potential and job security, while also providing current benefits and rewards.

Hotel A spends $£ 124$ per staff member, Hotel C spends $£ 193$ per staff member, Hotel D spends $£ 561$ per staff member, and Hotel $B$ spends the highest amount at $£ 778$ per staff member. It is interesting to note that the amounts, to a partial extent, indicate the relative levels of labour turnover between the hotels. Most of these preventive measures are neither related to length of service nor merit.

Hotels $\mathrm{B}$ and $\mathrm{C}$, being larger in size, employ more personnel staff. However it must be noted that Hotel $\mathrm{C}$ spends $£ 80$ more per staff member than Hotel $\mathrm{A}$. 


\begin{tabular}{|lllll|}
\hline $\begin{array}{l}\text { Table 5. Comparison of personnel costs and costs to prevent labour } \\
\text { turnover in London hotels }\end{array}$ & Hotel A & Hotel B & Hotel C & Hotel D \\
\hline & 22,300 & 296,346 & 90,850 & 106,600 \\
\hline $\begin{array}{l}\text { Total preventive } \\
\text { costs }\end{array}$ & 124 & 778 & 193 & 561 \\
$\begin{array}{l}\text { Cost per employee } \\
\text { General personnel } \\
\text { and training } \\
\text { costs }\end{array}$ & 61,000 & - & 197,290 & 25,000 \\
$\begin{array}{l}\text { No. of staff in } \\
\text { personnel dept. }\end{array}$ & 3 & 5 & 6 & 2 \\
\hline
\end{tabular}

\subsection{Absenteeism and appraisal systems}

Hotel $\mathrm{D}$ is the only hotel which does not provide a bonus in order to reduce absenteeism. Absenteeism is very low in Hotel $\mathrm{C}$, and sick pay at $£ 21$ per staff member could imply greater levels of job satisfaction--this could be marginally related to the fact that Hotel C is the only hotel of the four that offers flexi-time. Not surprisingly, sick pay per member of staff at Hotel $\mathrm{A}$ is $£ 139$, considerably higher than that of Hotel C.

From an investigation of appraisal systems - which should in theory positively affect the productivity and performance of the staff - a large disparity between the hotels was again found in all the hotels. New staff are appraised at all hotels. Hotel A, while carrying out this procedure at a very early stage never carries it out again.

Appraisal systems at the other hotels are more structured and regular. Both Hotels B and D involve their staff in this procedure and reward them. This has obvious implications for morale and motivation.

\begin{tabular}{|lcccc|}
\hline \multicolumn{4}{l}{ Table 6. Cost of absenteeism } & \\
\\
\hline Absenteeism & Hotel A & Hotel B & Hotel C & Hotel D \\
Total cost & 40,000 & 61,478 & 10,000 & - \\
\hline
\end{tabular}

\subsection{Analysis of individual hotels}

6.9.1. Hotel $A$. Recruitment selection and placement and induction costs at $£ 25,400$ are low while labour turnover is high. This could indicate lower quality staff being chosen, poorly inducted into departments and leaving rapidly due to subsequent maladjustment.

Unfortunately there is little to redress the balance as it can be seen that the general training and benefits at $£ 22,300$ are inferior to those available in comparable positions elsewhere. 
Without doubt, there will be a negative impact upon staff morale, job satisfaction and quality of customer care and servicc.

6.9.2. Hotel $B$. Selection and placement and induction costs at $£ 28,382$ are significantly lower than preventive costs at $£ 296,346$. Accordingly it could be argued that the importance of retaining and motivating staff has been completely over-estimated. (Even when considering that not all of the contributions and costs of preventive measures are directed exclusively towards reducing labour turnover.) It is quite possible that such high preventive costs are necessary to counteract inadequacies in earlier stages of the process. It should be noted that the cost-effectiveness of the personnel department, and its contribution to the long-term viability and profitability of the hotel is too important a consideration to be ignored.

6.9.3. Hotel $C$. It would appear that resources are allocated such that quality staff, deemed suitable, are initially recruited. These staff members are then comprehensively trained and extensively inducted, accordingly preventive measures can be justified.

However, further analysis indicates that despite comprehensive recruitment procedures, preventive measures are not effectively targeted at those positions which affect the core stability of the hotel. An aspect of significance is that due to the high costs incurred at every stage, high labour turnover will have a substantial impact upon this hotel.

6.9.4. Hotel D. Hotel D has the lowest labour turnover at $58.13 \%$, spending twice as much on preventive measures as Hotel $\mathrm{C}$, relative to size. From the analysis it could be implied that benefits and wages are important factors in retaining staff, although they might not necessarily improve service quality or staff satisfaction. All other costs have been favourably affected by low levels of turnover.

With regard to having a low level of labour turnover and effective financial control, Hotel D is in the most favourable position. However considerations of staff morale, job satisfaction, service quality and customer satisfaction, will invariably impact greatly upon the overall success of the hotel; these are not so measurable.

\section{Conclusion}

(a) Due to the complex and dynamic nature of labour turnover, it is difficult to accurately predict any one solution. The causes of turnover in the hotel industry have not to date been substantially documented. In addition to this, many of the turnover studies which deal with other industries may not be of relevance due to unique features specific to the hotel industry. The most effective remedies must therefore be customised to the particular labour turnover experience.

(b) In an attempt to lower labour turnover rates, many employers resort to impetuous and ill-conceived practices. The decision regarding financial expenditure to reduce labour turnover must instead be founded on the measurement of tangible waste and also on the estimation of the seriousness of the non-financial aspects. Management must therefore be guided by objective information of both a qualitative and quantitative nature. 
(c) The industry faces many labour challenges. The working population is undergoing structural changes and traditional sources of recruits are seriously depleted. The industry is experiencing a high growth rate with little increase in labour productivity (Hiemstra, 1990). These challenges underline the need for more relevant and flexible employment practices. Response to the needs of individual employees and the facilitation of personal development will ensure the alignment of manpower policy and social responsibilities. Such measures are necessary to improve overall job satisfaction.

'It is ironic that the hospitality industry which prides itself on providing service to its customers has been slow in applying the same principles to its own employees' (Hanson, 1988). As employees provide an important competitive advantage, cost-effective measures, designed to counteract high labour turnover, are therefore essential.

\section{References}

Atkinson, P. (1981) Motivating staff. Hospitality 24, 9-10.

Bevan, S. (1987) The Management of Labour Turnover. Report No. 137, Institute of Manpower Studies, Brighton, U.K.

Blennerhasset, E. (1983) Work Motivation and Personnel Practices. Institute of Public Administration, Dublin.

Gowler, D. and Legge, K. (1975) Labour Turnover and Retention, Pettman, B. E. (ed.). Gower Press, U.K.

Hanson. Q. (1988) Management techniques are best tools for employee retention. Nations Restaurant News 22 (28), F15.

Hiemstra, S. J. (1990) Employment policies and practices in the lodging industry. International Journal of Hospitality Management 9, $207-221$.

Hotel and Catering E.D.C. (1969) Staff Turnover. N.E.D.O., H.M.S.O., London.

Institute of Manpower Studies (1989) Recruitment Challenges. Tackling the Labour squeeze in Tourism and Leisure. I.M.S., Brighton, U.K.

Jamieson, L. (1990) Employees: how to find them, how to keep them. Canadian Hotel and Restaurant 68, part 6.

Jones, P. and Lockwood, A. (1989) The Management of Hotel Operations, An Innovative approach to the Study of Hotel Management. Cassell, U.K.

Kiely, J. (1986) The dynamics of job satisfaction-a longitudinal study. Personnel Review 15, 7-13.

Knight, I. B. (1971) Patterns of Labour Mobility in the Hotel and Catering Industry. H.C.I.T.B., London.

Legate, P. (1985) Five star facilities for staff. Hospitality 63, 6-7.

Magnan, L. B. (1990/91) The service industry is in need of help. Arizona Hospitality Trends, Arizona Hospitality Research Centre 5, 1-8.

McFillan, J., Riegel, C. D. and Enz, C. A. (1986) Why restaurant managers quit (and how to keep them). The Cornell Hotel \& Restaurant Quarterly 27, 37-43.

Palmer, G. L. et al. (1972) The Reluctant Job Changer. University of Pennsylvania Press, Philadelphia, U.S.A.

Pettman, B. O. (Ed.) (1974) Labour Turnover and Retention. A Gower Press Special Study, U.K.

Samuel, P. J. (1969) Labour Turnover-Towards a Solution. Institute of Personnel Management, London.

Wild, R. and Dawson, A. (1972) Labour Turnover Theories and Remedial Action. M.C.B. Ltd, U.K.

Woods, R. and Macauley, J. F. (1989) 'R' for turnover: retention programmes that work. The Comell Hotel and Restaurant Quarterly 30, 79-90. 


\section{About the Authors}

Ann Denvir recently completed her B.Sc.(Hons) degree in Hotel and Catering Management. She has worked in the personnel department of a large London hotel and is now undertaking postgraduate studies at the London School of Economics.

Frank McMahon is Deputy Principal of the Dublin College of Catering. He is former Secretary of the International Association of Hotel Management Schools and has been a member of the Editorial Board of the International Journal of Hospitality Management since its inception. 